\title{
Comparison of Phytochemical Composition, Free Radical Scavenging Activity, and Antimicrobial Activity of Selected Herbs Against Two Foodborne Pathogenic Bacteria
}

\author{
Manjula Bomma, Lam Duong, Srinivas Rao Mentreddy, Florence Okafor, Qunying Yuan* \\ Department of Biological and Environmental Sciences, College of Agriculture and Life Sciences, Alabama A\&M University, Alabama, the \\ United States \\ Email address: \\ manjula.bomma@aamu.edu (M. Bomma), iduong@bulldogs.aamu.edu (L. Duong), srinivasa.mentreddy@aamu.edu (S. R. Mentreddy), \\ florence.okafor@aamu.edu (F. Okafor), qunying.yuan@aamu.edu (Q. Yuan) \\ ${ }^{*}$ Corresponding author
}

\section{To cite this article:}

Manjula Bomma, Lam Duong, Srinivas Rao Mentreddy, Florence Okafor, Qunying Yuan. Comparison of Phytochemical Composition, Free Radical Scavenging Activity, and Antimicrobial Activity of Selected Herbs Against Two Foodborne Pathogenic Bacteria. American Journal of Biomedical and Life Sciences. Vol. 9, No. 3, 2021, pp. 142-150. doi: 10.11648/j.ajbls.20210903.12

Received: April 18, 2021; Accepted: May 7, 2021; Published: June 7, 2021

\begin{abstract}
Spices and herbs, owing to their natural benefits to human health, are gaining momentum as food preservatives in recent years. Due to their antioxidant activity, their extracts with bioactive principles form the basis of pharmaceutical and food processing applications. Two of such crops, mountain mint (Pycnanthemum virginianum) and red turmeric (Curcuma longa), were compared for their phytochemical composition, the antioxidant activity of methanolic extracts, and their antimicrobial activity against foodborne pathogenic bacteria, Listeria monocytogenes, Salmonella enteritidis in this study. Our results showed that the mountain mint had higher total phenolic content and total tannin content: $614.41 \pm 3.96$ and $529.74 \pm 4.39 \mathrm{mg}$ gallic acid equivalents/gram dry weight extract. In comparison, red turmeric had higher total flavonoid content: $1250.51 \pm 8.10 \mathrm{mg}$ catechin equivalents/gram dry weight extract. A lower $\mathrm{IC}_{50}$ value $(21.39 \pm 0.86 \mu \mathrm{g} / \mathrm{mL})$ of red turmeric reflected its higher antioxidant activity. A lower concentration of methanolic extract of red turmeric rhizome was needed for both MIC (62.5 and $125 \mu \mathrm{g} / \mathrm{mL})$ and MBC (125 and $250 \mu \mathrm{g} / \mathrm{mL})$ assay against L. monocytogenes and $S$. enteritidis, respectively. In conclusion, these findings showed the red turmeric methanolic extract as a source of potential phytochemicals and antioxidants exhibited relative efficiency with antimicrobial activity against two common foodborne pathogens. The results have implications for use in processed food preservation and protection against food spoilage pathogens.
\end{abstract}

Keywords: Crude Extracts, Phytochemical Components, Antioxidant Activity, Antibacterial Activity, Mountain Mint, Red Turmeric

\section{Introduction}

There is a decrease in the utilization of synthetic food additives due to the growing concerns about the risk of synthetic additives for human health [1,2]. Therefore, new eco-friendly methods, mainly plant extracts to reduce pathogenic bacteria growth and prolong shelf-life of food products, are being investigated as effective natural preservatives $[3,4]$. The medicinal plant species, such as spices and herbs containing bioactive phytochemicals, such as flavonoids, alkaloids, tannins, and terpenoids, have been reported as antimicrobials and antioxidants [5], anticarcinogenic, anti-allergic, antimutagenic, anti-inflammatory, and hypoglycemic properties [6]. The other chemical constituents of phenolics, glycosides, steroids, and saponins are utilized as crude drugs for pharmacological applications $[7,8]$. They have effectively protected human health against chronic diseases such as coronary heart disease, Alzheimer's disease, and cancer $[9,10]$. The phytochemical profiles and antimicrobial activity of plants against a wide range of bacteria have been reported [11-15]. The antimicrobial activities of many commonly used herbal spices allow them to be used for raw and processed food preservation, pharmaceuticals, alternative medicines, and natural therapies [16]. Indeed, spices and herbs can extend the shelf life of foods through their antioxidant or antimicrobial activity [17]. 
Also, these components could replace synthetic antioxidants to improve the quality and nutritional value of functional foods and offer additional health benefits [18].

The Mountain mint (Pycnanthemum virginianum), a perennial herbaceous plant, belongs to Lamiaceae [19]. The genus Pycnanthemum with about 20 species, is mainly distributed across the southern US [20, 21], and has an essential oil content that varies by species and ranges from pleasant floral and mint to pulegone (used as insect repellents and not suitable for culinary uses) [21]. Species such as $P$. virginianum have a pleasant mint flavor and are often used for making tea and as a medicine for treating coughs and fevers, and as a stimulant for mental fatigue [22].

Turmeric (Curcuma longa L.), a species of Zingiberaceae, is a rhizomatous plant native to southeast Asia, but it is extensively cultivated in tropical areas globally [23]. Turmeric is well known for its use in culinary, aromatic, cosmetic, and traditional herbal medicine [24]. The medicinal use of turmeric dates back to 4000 years [25]. Besides anecdotal and ethnic evidence, modern clinical studies have proved the medicinal properties of turmeric, including antioxidant, anti-inflammatory, antibacterial, and antifungal, $[26,27]$ anti-carcinogenic, antimutagenic, anticoagulant, antidiabetic, infertility, and many others [28]. The main bioactive turmeric is curcuminoids, such as curcumin, desmethoxycurcumin, and bisdemethoxycurcumin [29-31]. Turmeric's medical properties have been attributed to the curcuminoids, which are abundant in turmeric rhizome [32]. Curcumin, a potent antioxidant, the yellow polyphenol bioactive pigment, is believed to be the most bioactive and has displayed antioxidant, anti-inflammatory, antimicrobial effects [30, 33, 34], as well as shown significant health benefits and the potential to prevent various diseases, including Alzheimer's [35], coronary heart diseases, and cancer [36]. The two crops, mountain mint, and red turmeric, with potential for commercial cultivation in the southeastern US, have not been evaluated for their relative potency for inhibiting the growth of two common foodborne pathogenic bacteria, L. monocytogenes, $S$. enteritidis. Thus, the objectives of this research were: (1) to compare the bioactive components, total phenolic content, total flavonoid content, and total tannin content of the leaves of mountain mint and rhizomes of red turmeric variety, 'VN39'); (2) to determine the relative efficacy of free radical scavenging activity and antioxidant capacity of the methanolic extracts of the two medicinally active plant species; and (3) to examine the antimicrobial activity of crude methanolic extracts of mountain mint leaves and turmeric rhizomes against two foodborne pathogenic bacteria, L. monocytogenes (Grampositive bacteria), S. enteritidis (Gram-negative bacteria).

\section{Materials and Methods}

\subsection{Plant Collection}

The leaves of mountain mint and rhizomes of red turmeric variety VN39 accession were sourced from plants grown using organic production methods at the Alabama A\&M University Winfred Thomas Agricultural Research Station located in North Alabama at Latitude $34^{\circ} 89^{\prime} \mathrm{N}$ and longitude $86^{\circ} 56^{\prime} \mathrm{W}$. The dried plant materials of leaves of mountain mint and rhizomes of red turmeric were ground into a fine powder using a sterile blender. The dried powder was used for further extraction analyses.

\subsection{Extraction and Yield Determination}

Our previous study on the relative efficacy of chloroform and methanolic extracts of six Ocimum species (also belonging to the Lamiaceae family as the mountain mint used in this study) against pathogenic bacteria showed that the methanolic extracts were more efficient [37], it may be due to the maximum antibacterial compounds soluble in a polar solvent, methanolic extracts [38]. Thus, we chose methanol as the solvent to extract the bioactive compounds from the mountain mint leaves and turmeric rhizome.

About $10 \mathrm{~g}$ of dry material of each mountain mint leaves and red turmeric rhizome was placed in an amber-colored bottle containing $150 \mathrm{~mL}$ of absolute methanol and kept at room temperature for seven days. The soaked extracts were filtered using double filter paper (Whatman ${ }^{\mathrm{TM}}$ ), evaporating under room temperature. Their methanol extract dry weight was recorded and stored at four ${ }^{\circ} \mathrm{C}$ until further use [28]. The following formula (1) was used for calculating the dry yield percentage [39].

$$
\% \text { yield }=\frac{\text { dry weight extract }}{\text { initial dry raw material weight }} \times 100
$$

\subsection{Phytochemical Content}

\subsubsection{Determination of Total Phenolic Content}

The total phenolics from herbal extracts were determined using the Folin-Ciocalteu phenol reagent described by Molan and his co-workers [40], with modification. The stock solution of gallic acid at $5 \mathrm{mg} / \mathrm{mL}$ was prepared with distilled water, further diluted into concentrations ranging from 20 to $400 \mu \mathrm{g} / \mathrm{mL}$, and used as a standard calibration curve. $12.5 \mu \mathrm{L}$ of diluted (1:10) Folin - Ciocalteu's reagent: water at the (1:1) ratio was added to the standard or diluted herbal extract prepared a concentration of $1 \mathrm{mg} / \mathrm{mL}$ in a 96 well plate reader. The reaction was allowed to stay for 5 minutes at room temperature and followed by the addition of $125 \mu \mathrm{L}$ of $10 \%$ sodium carbonate. The reaction mixtures were incubated in the dark at room temperature for 90 minutes. The absorbance was measured at $750 \mathrm{~nm}$ using a spectrophotometer (800 TS microplate reader, Biotek, Vermont, USA) against the reagent blank. The total phenolic content of extracts was calculated as milligram of gallic acid equivalent per gram dry weight extract.

\subsubsection{Determination of Total Flavonoid Content}

The herbal extract total flavonoid content was determined using the aluminum chloride colorimetric assay method described by Chandra and his co-workers [41], with minor modifications. The catechin stock solution at a $5 \mathrm{mg} / \mathrm{mL}$ 
concentration was prepared using $80 \%$ ethanol and further diluted into concentrations ranging from 20 to $400 \mu \mathrm{g} / \mathrm{mL}$ and used as a standard calibration curve. $7.5 \mu \mathrm{L}$ of $5 \%$ $\mathrm{NaNO}_{2}$ was added to the $25 \mu \mathrm{L}$ of standard catechin or a diluted herbal extract prepared at the concentration of $1 \mathrm{mg} /$ $\mathrm{mL}$ in a 96 well plate. The reaction was incubated for 5 minutes at room temperature and followed by the addition of $15 \mu \mathrm{L}$ of $10 \%$ aluminium chloride $\left(\mathrm{AlCl}_{3}\right)$ dissolved in distilled water. The reaction was allowed to stand for 5 minutes at room temperature, followed by the addition of 50 $\mu \mathrm{L}$ of $1 \mathrm{~N} \mathrm{NaOH}$, and then $40 \mu \mathrm{L}$ of distilled water was sequentially added to each well. The absorbance of the reaction mixture at $515 \mathrm{~nm}$ was recorded using a spectrophotometer (Model 800 TS microplate reader, Biotek, Vermont, USA) against the blank. The total flavonoid content is expressed as a milligram of catechin equivalent per gram dry weight extract.

\subsubsection{Determination of Total Tannin Content}

The total tannin content was determined using the FolinCiocalteu phenol reagent described by Tambe and Bhambar [42], with slight modifications. A stock solution of gallic acid at $5 \mathrm{mg} / \mathrm{mL}$ was prepared with distilled water and further diluted into concentrations ranging from 20 to $400 \mu \mathrm{g} / \mathrm{mL}$ and used as a standard calibration curve. $12.5 \mu \mathrm{L}$ of diluted $(1: 10)$ Folin - Ciocalteu's reagent: water at the $(1: 1)$ ratio was added to the standard or diluted herbal extract prepared a concentration of $1 \mathrm{mg} / \mathrm{mL}$ in a 96 well plate. The reaction was incubated for 5 minutes at room temperature. This step was followed by the addition of $10 \%$ sodium carbonate of $125 \mu \mathrm{L}$, and then $50 \mu \mathrm{L}$ of distilled water was sequentially added to each well. These reaction mixtures were incubated in the dark at room temperature for 30 minutes. The absorbance was recorded at $750 \mathrm{~nm}$ using a spectrophotometer (800 TS microplate reader, Biotek, Vermont, USA) against the reagent blank. The total tannin content of extracts was calculated as milligram of gallic acid equivalent per gram dry weight extract.

\subsection{Antioxidant Assay with DPPH}

\section{(2,2-diphenyl-1-picrylhydrazyl) Radicals}

The DPPH assay was used to estimate the radical scavenging activities of the methanolic extracts from the two herbs described in reference [43], with modifications. Before the assay, the herb and ascorbic acid stock solution at a 1 $\mathrm{mg} / \mathrm{mL}$ concentration was dissolved in methanolic and water, respectively, and further diluted into concentrations ranging from 0 to $500 \mu \mathrm{g} / \mathrm{mL}$. The DPPH radical- methanol stock prepared at a dilution of (1:50) was used as a negative control, and ascorbic acid was used as the standard. The $200 \mu \mathrm{L}$ of DPPH radical solution was added to $40 \mu \mathrm{L}$ of the standard or herbal extract in a 96 well plate. The incubated samples were reacted with the stable DPPH radical in a methanol solution, and change in color (from deep violet to light yellow) were read at $515 \mathrm{~nm}$ [Absorbance (Abs)] after 30 minutes using a spectrophotometer (800 TS microplate reader, Biotek, Vermont, USA) against control. The scavenging activity determined using the following equation (2):

$$
\mathrm{AA} \%=100-\frac{(\text { Abs sample }- \text { Abs blank }) \times 100}{\text { Abs control }}
$$

$\mathrm{AA} \%$ is antioxidant percentage inhibition. Abs sample is the absorbance of DPPH in the presence of either a herb extract or the standard, and Abs blank is the absorbance of methanol. Abs control is the absorbance of DPPH alone.

The percentage of each sample's antioxidant activity was calculated, and the inhibition curve was established by plotting the inhibition percentage against the log concentration of the extract. Their $\mathrm{IC}_{50}$ (microgram concentration required to inhibit DPPH radical formation by $50 \%$ ) was identified from the inhibition curve.

\subsection{Test Microorganisms}

Two foodborne bacterial species, L. monocytogenes, and $S$. enteritidis, used in the present study, were purchased from Presque Isle Cultures (Erie, PA, USA). Luria-Bertani medium (LB) was used for sub-cultured microorganisms.

\subsection{Determination of Minimum Inhibitory Concentrations (MIC) and Minimum Bactericidal Concentrations $(M B C)$}

MIC of mountain mint leaves and turmeric rhizome crude methanolic extracts was determined in 96-well microtiter plates against common food pathogenic bacteria described previously $[44,45]$. Herbal crude extracts were dissolved in $1 \%$ $(\mathrm{w} / \mathrm{v})$ in DMSO. DMSO alone was used as a negative control; antibiotics, chloramphenicol at concentrations of 4.37, 8.75, and $17.5 \mu \mathrm{g} / \mathrm{mL}$, and kanamycin at concentrations of $(5,2.5 \mu \mathrm{g} / \mathrm{mL})$, were used as a positive control. Briefly, $195 \mu \mathrm{L}$ of $24 \mathrm{~h}$ grown bacteria, at a final density of $\sim 10^{5} \mathrm{CFU} / \mathrm{mL}$, was loaded into microtiter plates, followed by the addition of $5 \mu \mathrm{L}$ of extracts of mountain mint and red turmeric stock at concentrations ranging from $2.5,5,10,20,30$, and $40 \mathrm{mg} / \mathrm{mL}$ into wells in triplicates. The bacteria were then cultivated at $37^{\circ} \mathrm{C}$ with a continuous shake at $240 \mathrm{rpm}$ for $24 \mathrm{~h}$. After incubation, the wells were examined for microbial growth by observing turbidity. The lowest concentration of herbal extract indicates no visible growth of bacteria by the eye was considered MIC. Results are expressed in $\mu \mathrm{g} / \mathrm{mL}$. Further, the MBC was determined by subcultivation of $200 \mu \mathrm{L}$ of the above 24 -hour culture from the wells that didn't exhibit visible growth onto the agar plate and incubated for $24 \mathrm{~h}$ at $37^{\circ} \mathrm{C}$. The lowest concentration of herb extract indicating at least $99 \%$ killing of the original inoculum was considered the MBC. All experiments for MIC and MBC were performed in triplicates.

\subsection{Statistical Analysis}

The experiments were done in triplicates and expressed as mean $\pm \mathrm{SD}$. Student $t$-test was used to compare the differences between groups. p-value $<0.05$ were considered significant. 


\section{Results}

\subsection{Extraction and Yield}

Two herbs, mountain mint and, red turmeric were grown in open field experiments in one location. In this study, there was a significant difference in the yield of the extracts a

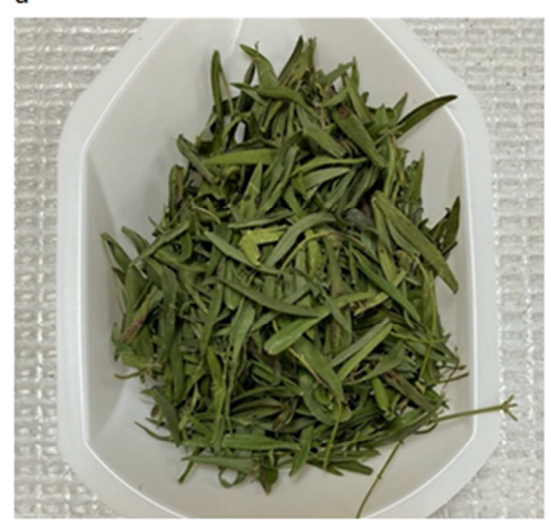

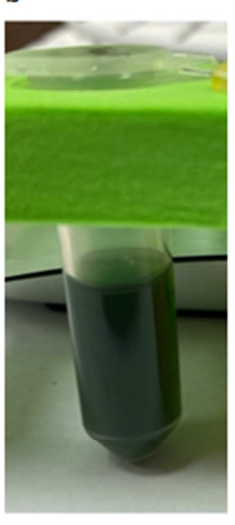

between herbs. The methanol extract yield of mountain mint leaves and the red turmeric rhizome was $12.0 \pm 0.03$ and $8.8 \pm 0.04 \mathrm{~g} / 100 \mathrm{~g}$ of dry raw material. The methanolic extracts of mountain mint leaves had a green color, while that of red turmeric rhizome has golden yellow solutions (Figure 1b and d).

C

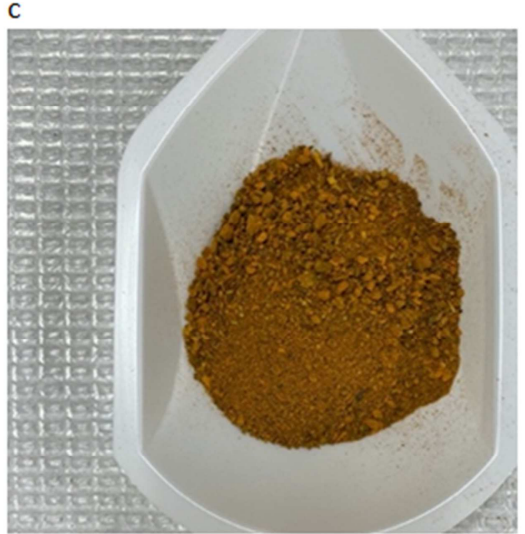

d

RT

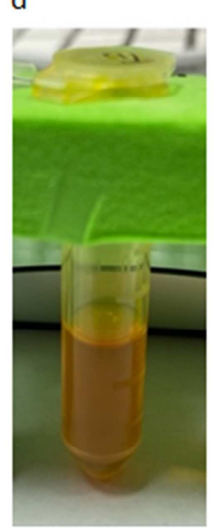

Figure 1. Two selected dry mountain mint and red turmeric and their methanolic extracts.

$\mathrm{MM}=$ mountain mint

$\mathrm{RT}=$ red turmeric

$\mathrm{a}$ and $\mathrm{b}=$ mountain mint leaves and their methanolic extract

$\mathrm{c}$ and $\mathrm{d}=$ red turmeric rhizome and their methanolic extract

Table 1. The methanolic extract yield of mountain mint and red turmeric.

\begin{tabular}{lll}
\hline Parameters & MM & RT \\
\hline Initial dry raw material weight (g) & 10 & 10 \\
Methanolic extract dry weight (g) & $1.2 \pm 0.03^{*}$ & $0.88 \pm 0.04$ \\
Yield (\%) & $12.0 \pm 0.02^{*}$ & $8.8 \pm 0.03$ \\
\hline
\end{tabular}

Yield (\%) expressed (g per $100 \mathrm{~g}$ dry raw material), as the mean \pm SD. $\left({ }^{*}\right.$, MM compared to RT, p<0.05; $\mathrm{n}=3$ ).

$\mathrm{MM}=$ mountain mint

$\mathrm{RT}=$ red turmeric

\subsection{Phytochemical Contents of Herbal Extracts}

The total phenolic content, total flavonoid content, and total tannin content of the herbal extracts were expressed as the mean value of their standard equivalents, $\mathrm{mg} / \mathrm{g}$ dry weight extract, and shown in Table 2. The level of total phenolic content $(614.41 \pm 3.96 \mathrm{mg} / \mathrm{g})$ and total tannin content $(529.74 \pm 4.39 \mathrm{mg} / \mathrm{g})$ of mountain mint was $8.6 \%$ and $21 \%$ higher than those of red turmeric, respectively, and their mean value is expressed in terms of gallic acid equivalent, and the standard curve equation was: $\mathrm{Y}=0.0016 \mathrm{x}+0.1428$, $\mathrm{R}^{2}=0.9951$ and $\mathrm{Y}=0.0017 \mathrm{x}+0.1017, \mathrm{R}^{2}=0.9918$, for total phenolics and total tannin, respectively. The total phenol content and total tannin content level of mountain mint were calculated from the above equations using gallic acid as standard. The mean of total flavonoid content $(1250.51 \pm 8.10$ $\mathrm{mg} / \mathrm{g}$ ) of red turmeric was $86 \%$ higher than that of mountain mint leaves $(497.43 \pm 11.83 \mathrm{mg} / \mathrm{mL})(\mathrm{p}<0.05)$. The level of total flavonoid content was obtained from the regression curve using catechin as standard. Their mean value is expressed in terms of catechin equivalent (the standard curve equation is $\left.\mathrm{Y}=0.0012 \mathrm{x}+0.1594, \mathrm{R}^{2}=0.9608\right)$.

Table 2. The total phenolic, flavonoid, tannin contents activity of methanolic extracts of mountain mint and red turmeric.

\begin{tabular}{llll}
\hline Plant species & Total phenolic content $\left(\mathbf{m g ~ G A E}^{\mathbf{1} / \mathbf{g} \text { DWE) }}\right.$ & Total flavonoid content (mg CE $/ \mathbf{g ~ D W E )}$ & Total Tannin content (mg GAE $/ \mathbf{g}$ DWE) \\
\hline MM & $614.41 \pm 3.96^{*}$ & $497.43 \pm 11.83$ & $529.74 \pm 4.39^{* * *}$ \\
RT & $562.98 \pm 3.81$ & $1250.51 \pm 8.10^{* *}$ & $430.07 \pm 3.90$ \\
\hline
\end{tabular}

Data expressed as (mean $\pm \mathrm{SD})$. (* compare total phenolic content between MM and RT; ** compare total flavonoid content between MM and RT; ${ }^{* *}$ compare total tannin content between MM and RT. In all three comparisons, $\mathrm{p}<0.05 ; \mathrm{n}=3$ ).

$\mathrm{MM}=$ mountain mint

$\mathrm{RT}=$ red turmeric

1-milligram gallic acid equivalents (mg GAE) per gram of dry weight extract (DWE)

2-milligram catechin equivalents ( $\mathrm{mg} \mathrm{CE}$ ) per gram of dry weight extract (DWE) 


\subsection{DPPH Scavenging Assay}

DPPH free radical-scavenging activity of the methanolic extracts of the two herbs was examined to determine their antioxidant properties. Ascorbic acid was used as a standard to evaluate the free radical scavenging activity of the two herb extracts. The maximum inhibition on DPPH free radical level by standard ascorbic acid was $96.34 \pm 0.16 \%$ at a $125 \mu \mathrm{g} / \mathrm{mL}$ concentration. In comparison, mountain mint and red turmeric were $94.02 \pm 0.10 \%$ and $91.0 \pm 0.44 \%$ at a $250 \mu \mathrm{g} / \mathrm{mL}$ concentration, respectively. The efficiency of inhibition by ascorbic acid, mountain mint, and red turmeric at different concentrations was plotted as a percentage of inhibition against concentration in Figure 2. The relationship between logarithm concentration and percentage of inhibition was fit in the function: $\mathrm{y}=97.38442 *\left(1-\operatorname{Exp} \quad\left(-0.348053 \times 1^{\wedge} 1.91444717\right)\right)$, $y=93.68442^{*} \quad\left(1-\operatorname{Exp} \quad\left(-0.368053 \times 1^{\wedge} 2.51444717\right)\right)$, $\mathrm{y}=99.68442 * \quad\left(1-\operatorname{Exp}\left(-0.358053 \times 1^{\wedge} 2.81444708\right)\right.$ of mount mint, red turmeric, and ascorbic acid, respectively, in which y represents the percentage of inhibition, $\mathrm{x}$ represents the logarithm concentration. $\mathrm{IC}_{50}$ of ascorbic acid and the two herb extracts were estimated from the functions, and their values are presented in Table 3. The $\mathrm{IC}_{50}$ value of red turmeric was significantly higher than that of mountain mint. The $\mathrm{IC}_{50}$ of ascorbic acid: $17.96 \pm 1.53$, was the lowest when compared to red turmeric: $21.39 \pm 0.86$, and mountain mint: $26.16 \pm 2.10$ $\mu \mathrm{g} / \mathrm{mL}$. The $\mathrm{IC}_{50}$ of red turmeric extract is significantly lower than that of mount mint leave extract (Figure $2, \mathrm{p}<0.05 ; \mathrm{n}=3$ ).

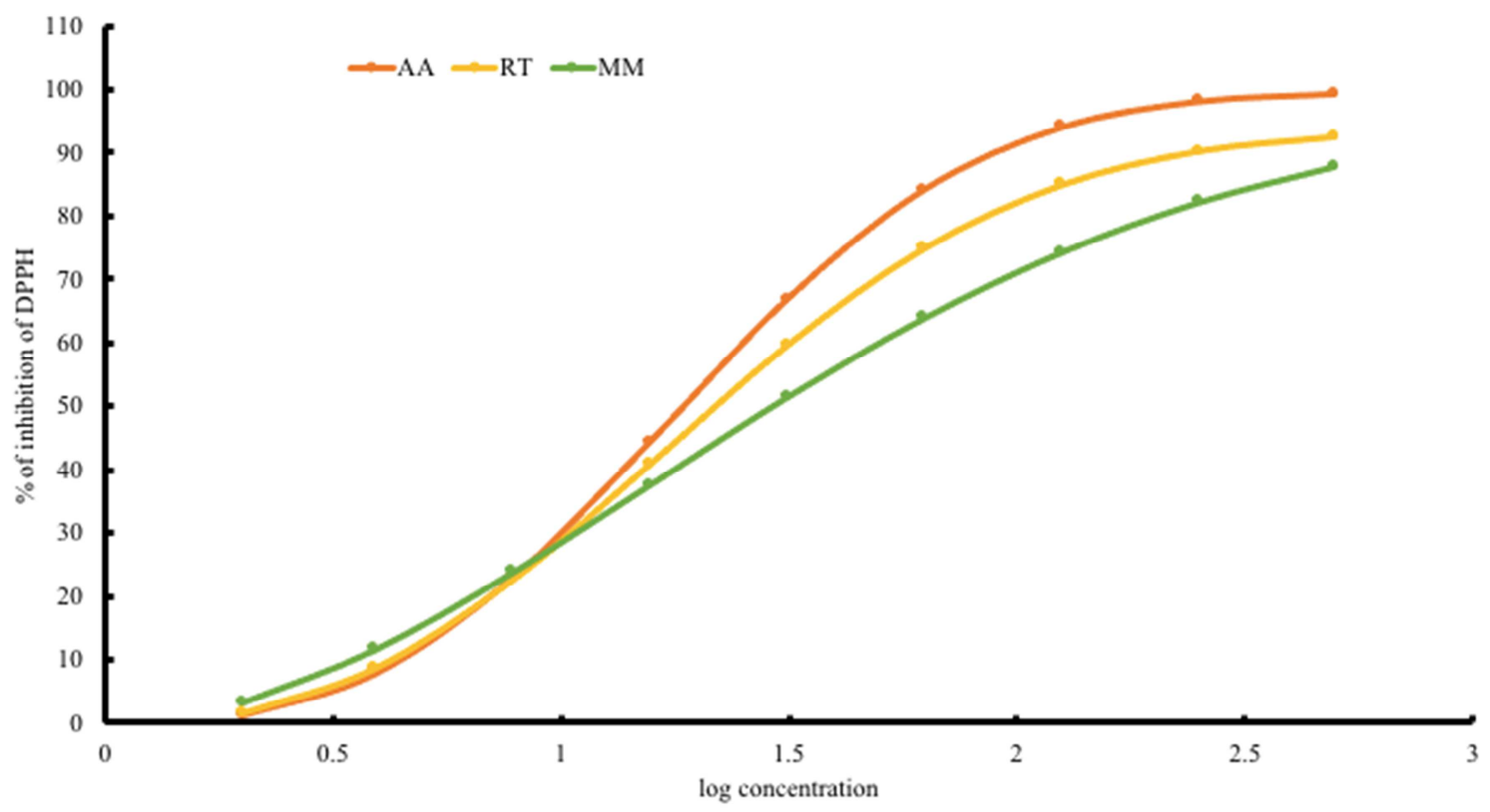

Figure 2. DPPH radical scavenging activity of methanolic extracts of mountain mint, red turmeric, and ascorbic acid.

Data expressed as (mean $\pm \mathrm{SD})$

MM=mountain mint

$\mathrm{RT}=$ red turmeric

$\mathrm{AA}=$ ascorbic acid

Table 3. IC $C_{50}$ of DPPH radical scavenging activity of mountain mint, red turmeric, and ascorbic acid.

\begin{tabular}{llll}
\hline IC $_{50}$ for DPPH scavenging & MM & RT & AA (standard) \\
\hline$\mu \mathrm{g} / \mathrm{mL}$ & $26.16 \pm 2.10^{*}$ & $21.39 \pm 0.86^{* *}$ & $17.96 \pm 1.53^{* * *}$ \\
\hline
\end{tabular}

Data expressed as (mean $\pm \mathrm{SD})$. (*, comparison of $\mathrm{IC}_{50}$ between $\mathrm{MM}$ and $\mathrm{RT}$; **, comparison of $\mathrm{IC}_{50}$ between $\mathrm{RT}^{*}$ and $\mathrm{AA} ;{ }^{* * *}$, comparison of $\mathrm{IC}_{50}$ between $\mathrm{AA}$ and MM. In all three comparisons, $\mathrm{p}<0.05 ; \mathrm{n}=3)$.

$\mathrm{IC}_{50}: 50 \%$ of inhibitory concentration.

$\mathrm{MM}=$ mountain mint

$\mathrm{RT}=$ red turmeric

$\mathrm{AA}=$ ascorbic acid

\section{4. $M I C$ and $M B C$}

The antimicrobial activity of the methanolic herbal extracts was evaluated by determining the MIC and MBC against L.monocytogenes and $S$. enteritidis. As shown in Table 4, the MIC of mountain mint and red turmeric was 500 and $62.5 \mu \mathrm{g} / \mathrm{mL}$ against L.monocytogenes, respectively. The $\mathrm{MBC}$ of mountain mint and red turmeric was 750 and 125 $\mu \mathrm{g} / \mathrm{mL}$ against L.monocytogenes, respectively. Both MIC and MBC of mountain mint were $1000 \mu \mathrm{g} / \mathrm{mL}$ against $S$. enteritidis, while the MIC, MBC of red turmeric were 125 and $250 \mu \mathrm{g} / \mathrm{mL}$ against $S$. enteritidis, respectively. The MIC 
and MBC of chloramphenicol were lower than $0.11 \mu \mathrm{g} / \mathrm{mL}$ against L.monocytogenes and $S$. enteritidis, respectively, and these of kanamycin was $(0.06$ and $0.125 \mu \mathrm{g} / \mathrm{mL})$ against
L.monocytogenes, respectively. The MIC, MBC of kanamycin were lower than $0.06 \mu \mathrm{g} / \mathrm{mL}$ against $S$. enteritidis, respectively.

Table 4. Antibacterial activity of the methanolic extracts of mountain mint, red turmeric against selected foodborne pathogenic bacteria.

\begin{tabular}{|c|c|c|c|c|c|c|c|c|c|c|}
\hline & MM & & RT & & CLP & & $\mathbf{K M}$ & & DMSC & \\
\hline & MIC & MBC & MIC & MBC & MIC & MBC & MIC & MBC & MIC & MBC \\
\hline LM & 500 & 750 & 62.5 & 125 & $<0.11$ & $<0.11$ & 0.06 & 0.125 & NA & NA \\
\hline SE & 1000 & 1000 & 125 & 250 & $<0.11$ & $<0.11$ & $<0.06$ & $<0.06$ & NA & NA \\
\hline
\end{tabular}

MIC and MBC values are given as $(\mu \mathrm{g} / \mathrm{mL})$. Data expressed as (mean; $\mathrm{n}=3)$.

$\mathrm{MM}=$ mountain mint

RT=red turmeric

$\mathrm{CLP}=$ chloramphenicol

$\mathrm{KM}=$ kanamycin

$\mathrm{DMSO}=$ dimethyl sulfoxide

$\mathrm{LM}=$ Listeria monocytogenes

$\mathrm{SE}=$ Salmonella enteritidis

$\mathrm{NA}=$ no activity

\section{Discussion}

This is the first study to compare the two selected herbs, mountain mint leaves, and red turmeric rhizome, for their methanolic extract yield, phytochemical contents, antioxidant properties, and antimicrobial activity against two foodborne pathogenic bacteria. Over the years, plants and plant materials have been used to treat many diseases and infections [28] and replace synthetic chemical preservatives in food processing. To explore the potential application of mountain mint leaves and turmeric rhizome as natural and safe food preservatives, we assessed their antimicrobial and antioxidant activity in this study. We disclosed a significant difference in the extract yield (Table 1) and a significant difference in the level of total phenolic content, total flavonoid content, and total tannin content in the two crops (Table 2). The mountain mint had a higher extract yield and a higher total phenolic content and total tannin content, whereas total flavonoid content was higher in red turmeric (Table 2).

The high content of polyphenolic constituents, which in turn could be the basis for better biological and physiological properties, including antimicrobial, antioxidant activities of herb species $[13,15]$. The oxidation-reduction potential of flavonoids, polyphenols (phenolic acids, tannins, stilbenes, and lignans) that contain hydroxyl groups play an essential role in neutralizing free radicals [46] and allow them to act as reducing agents, hydrogen donors, and singlet oxygen quenchers [47]. To prove that the crude extracts of mountain mint and red turmeric did have good antioxidant activity, the antioxidant activity of the two herbs in the current study was determined using free radical scavenging DPPH assay [47]. The maximum inhibition of DPPH scavenging activity of mountain mint leaf and red turmeric rhizome was about $90 \%$, similar to that of the standard ascorbic acid but at a higher concentration (Figure 2). However, the $\mathrm{IC}_{50}$ should be a better index of the scavenging activity on DPPH. A low $\mathrm{IC}_{50}$ refers to a high antioxidant capacity [48]. The red turmeric rhizome had a low $\mathrm{IC}_{50}$, suggesting that the red turmeric rhizome may be a stronger antioxidant.

Interestingly, the red turmeric rhizome only had a higher level of flavonoids than mountain mint leaves (Table 3 ). In comparison, the level of total phenolics and total tannin were lower than those in mount mint leaves. Flavonoids can scavenge hydrogen radicals, superoxide anions, and lipid peroxyl radicals. Therefore, our study suggested that the more potent antioxidant activity of the red turmeric was probably attributed to its higher content of flavonoids (Table 3).

Phytochemicals have a significant therapeutic application, serve as a prototype to develop less toxic and more effective medicines in controlling the growth of microorganisms [49]. We examined the antimicrobial screening activity of mountain mint leaves and red turmeric rhizomes. The MIC and MBC were employed to evaluate the effectiveness of the crude extracts at different concentrations on the bacteria used in this study. The plant extracts with high activity against a pathogenic microorganism usually have low MIC value, while the extracts with low activity have high MIC value [50]. This study found that crude methanolic extracts of red turmeric rhizome had higher efficiency in inhibiting the growth of foodborne pathogenic bacteria (Table 4), which corresponded to its significantly higher levels of flavonoids (Table 2 and Table 4). Thus, our results suggested their differential activity on bacteriostatic and bactericidal effect against tested bacteria was associated with the difference in flavonoid levels in the extracts from these herbs. Furthermore, we noticed that red turmeric rhizome extract showed higher activity against L. monocytogenes than S. enteritidis (Table 4). This is similar to the study conducted by Chandarana and his co-workers [51], in which they showed that there was a decreasing order of sensitivity against Gram-positive to Gram-negative from three Zingiberaceae spices of heated, unheated decoctions and solvent extracts as follows: B. subtilis $>$ S. aureus $>$ E. coli. The difference in the sensitivity between Gram-negative and Gram-positive bacteria could be probably due to the protective effects of Gram-negative bacteria against the 
hydrophobic antimicrobial compounds [52, 53], and penetration barrier towards intake of any foreign compounds, including macromolecules [50].

Our results showed that even though mountain mint leaves were rich in total phenolic content and total tannin content, their antioxidant, and antibacterial efficiency were lower than red turmeric rhizome. The higher number of hydroxyl groups on the phenolic group (degree of hydroxylation) or the higher oxidized state are thought to correlate with phenolics' higher toxicity against microorganisms [54]. The phenolics in mountain mint may have a lower number of hydroxyl groups or a lower level of oxidized phenolic content. Moreover, flavonoids with different configurations or hydroxylation at different positions showed other antimicrobial activity. The red turmeric may likely contain more potent flavonoid species than mountain mint [55]. Thus, we displayed that the high content of secondary metabolites, mainly flavonoids, and the consequent antioxidant activity may allow red turmeric botanicals to be potentially applied as food preservatives to reduce food spoilage or antimicrobial agents to prevent infectious diseases.

\section{Conclusion}

This study demonstrated the interspecific variation among turmeric and mountain mint for bioactive components, phenolics, flavonoids, tannins, free radical scavenging potential, antimicrobial activity against two common foodborne pathogens, Listeria monocytogenes and Salmonella enteritidis. A low $\mathrm{IC}_{50}$ of DPPH inhibition, MIC, and $\mathrm{MBC}$ of red turmeric could good factors for its practical applications in functional foods and a natural additive to replace synthetic preservatives and the potential to be an antimicrobial agent.

\section{Acknowledgements}

This research was funded by Project No. 2016-6800624785 of the USDA/National Institute of Food and Agriculture (NIFA)-Agriculture and Food Research Initiative (AFRI) and project No. W911NF1810444 of Department of Defense-Army Research Office. The authors thank Ms. Andrea Barr, Ms. Mounika Pudota, Ms. Jasmine Arnold, Mr. Lewis Bingham, and Dr. Suresh Kumar for their assistance with field trials and post-harvest processing.

\section{References}

[1] C. Caleja, L. Barros, A. L. Antonio, M. Carocho, M. B. P. P. Oliveira, and I. C. F. R. Ferreira, "Fortification of yogurts with different antioxidant preservatives: A comparative study between natural and synthetic additives," Food Chem., vol. 210, pp. 262-268, 2016.

[2] I. K. Kalem, Z. F. Bhat, S. Kumar, and A. Desai, "Terminalia arjuna: A novel natural preservative for improved lipid oxidative stability and storage quality of muscle foods," Food Sci. Hum. Wellness, vol. 6, no. 4, pp. 167-175, 2017.
[3] J. Fernández-López, N. Zhi, L. Aleson-Carbonell, J. A. PérezAlvarez, and V. Kuri, "Antioxidant and antibacterial activities of natural extracts: Application in beef meatballs," Meat Sci., vol. 69, no. 3, pp. 371-380, 2005.

[4] D. Clarke et al., "Surface attachment of active antimicrobial coatings onto conventional plastic-based laminates and performance assessment of these materials on the storage life of vacuum packaged beef sub-primals," Food Microbiol., vol. 62, pp. 196-201, 2017.

[5] W. H. Talib and A. M. Mahasneh, "Antimicrobial, cytotoxicity and phytochemical screening of Jordanian plants used in traditional medicine," Molecules, vol. 15, no. 3, pp. 1811-1824, 2010.

[6] D. Alesiani et al., "Antioxidant and antiproliferative activities of phytochemicals from Quince (Cydonia vulgaris) peels," Food Chem., vol. 118, no. 2, pp. 199-207, 2010.

[7] Y. Andriani et al., "Phytochemical analysis, antioxidant, antibacterial and cytotoxicity properties of keys and cores part of Pandanus tectorius fruits," Arab. J. Chem., vol. 12, no. 8, pp. 3555-3564, 2019.

[8] S. ANTARA and A. BATRA, "Evaluation of antimicrobial activity of different solvent extracts of medicinal plant: Melia azedarach L," Int. J. Curr. Pharm. Res., vol. 4, no. 2, pp. 6773, 2012.

[9] B. Kirkan, M. S. Ozer, C. Sarikurkcu, M. Copuroglu, M. Cengiz, and B. Tepe, "Can the stalks of Papaver somniferum L. be an alternative source of bioactive components?," Ind. Crops Prod., vol. 115, no. February, pp. 1-5, 2018.

[10] Z. Sun, H. Wang, J. Wang, L. Zhou, and P. Yang, "Chemical composition and anti-inflammatory, cytotoxic and antioxidant activities of essential oil from leaves of Mentha piperita grown in China," PLoS One, vol. 9, no. 12, pp. 1-15, 2014.

[11] A. S. Okmen, G. Okmen, A. Arslan, and M. Vurkun, "Antibacterial activities of Mentha piperita L. extracts against bacteria isolated from soccer player's shoes and its antioxidant activities," Indian J. Pharm. Educ. Res., vol. 51, no. 3, pp. S163-S169, 2017.

[12] S. Akhtar et al., "Polyphenol-rich extracts of traditional culinary spices and herbs and their antibacterial activity in minced beef," J. Food Qual., vol. 2019, 2019.

[13] M. M. Mashilo and M. Peter, "Phytochemical analysis, antioxidant, antibacterial and combinational effects of medicinal plants used by Bapedi traditional healers to prepare herbal mixtures," J. Med. Plants Res., vol. 12, no. 29, pp. 563-574, 2018.

[14] U. Srivastava, S. Ojha, N. N. Tripathi, and P. Singh, "In vitro antibacterial, antioxidant activity and total phenolic content of some essential oils," J. Environ. Biol., vol. 36, no. 6, pp. 1329-1336, 2015.

[15] K. Shanmugapriya, D. Nityanandi, and P. S. Saravana, "Evaluation of antioxidant, anti-inflammatory and antimicrobial activities of two different extracts of Camellia sinensis (L.) O. Kuntze," Int. J. Drug Dev. Res., vol. 5, no. 3, pp. 155-168, 2013.

[16] V. V Panpatil, S. Tattari, N. Kota, C. Nimgulkar, and K. Polasa, "In vitro evaluation on antioxidant and antimicrobial activity of spice extracts of ginger, turmeric and garlic," $J$. Pharmacogn. Phytochem., vol. 2, no. 3, pp. 143-148, 2013. 
[17] R. Dhiman, N. Aggarwal, K. R. Aneja, and M. Kaur, "In Vitro Antimicrobial Activity of Spices and Medicinal Herbs against Selected Microbes Associated with Juices," Int. J. Microbiol., vol. 2016, 2016.

[18] M. B. Hossain, N. P. Brunton, C. Barry-Ryan, A. B. MartinDiana, and M. Wilkinson, "Antioxidant activity of spice extracts and phenolics in comparison to synthetic antioxidants," Rasayan J. Chem., vol. 1, no. 4, pp. 751-756, 2008.

[19] USDA, "Plants Profile for Pycnanthemum virginianum (Virginia mountainmint)," 2021. [Online]. Available: https://plants.usda.gov/core/profile?symbol=PYVI.

[20] B. Pleasant, "Mother Earth Living, plant profile, herb to know montain mint." pp. 1-2, 2008.

[21] S. Betz, D. Knapke, K. Schlosser, D. Stravinsky, and L. Wells, "The Herb Society of America's Notable Native 2016 Mountain Mints," 2015.

[22] S. Foster and J. A. Duke, A field guide to medicinal plants: Eastern and central North America. National Audubon Society., National Wildlife Federation., \& Roger Tory Peterson Institute. Boston: Houghton Mifflin., 1990.

[23] P. Awasthi and S. Dixit, "Chemical composition of Curcuma Longa leaves and rhizome oil from the plains of Northern India," J. Young Pharm., vol. 1, no. 4, p. 312, 2009.

[24] C. F. Helen, R. H. Su, and J. Ghulam, "Isolation, purification and characterization of insect repellents from Curcuma longa L.," J. Agr. Food Chem., vol. 30, pp. 290-292, 1982.

[25] S. Prasad and B. B. Aggarwal., "Turmeric, the Golden spice: From Traditional Medicine to Modern Medicine," in Herbal Medicine: Biomolecular and Clinical Aspects., 2ndediti ed., I. Benzie and S. Wachtel-galor, Eds. Boca Raton (FL): CRC Press/Talor \& Francis, 2011, pp. 1-20.

[26] R. S. Bomdyal, M. U. Shah, Y. S. Doshi, V. A. Shah, and S. P. Khirade, "Antibacterial activity of curcumin (turmeric) against periopathogens - An in vitro evaluation," J. Adv. Clin. Res. Insights, vol. 4, no. 6, pp. 175-180, 2017.

[27] A. Ikpeama, G. I. Onwuka, and C. Nwankwo, "Nutritional composition of tumeric (Curcuma longa) and its antimicrobial properties," Int. J. Sci. Eng. Res., vol. 5, no. 10, pp. 10851089,2014

[28] Mbah-Omeje and K. Nkechinyere, "In Vitro Study on the Antimicrobial Activity of Curcuma Longa Rhizome on Some Microorganism," Am. J. Biomed. Life Sci., vol. 7, no. 1, p. 1, 2019.

[29] T. Hamaguchi, K. Ono, and M. Yamada, "Curcumin and Alzheimer's disease," CNS Neurosci. Ther, vol. 16, pp. 285297, 2010.

[30] A. Jain and D. K. Parihar, "Nutritional Evaluation of Curcuma Species Collected from Different Agro Climatic Regions of Chhattisgarh," Am. J. Ethnomedicine, vol. 04, no. 02, pp. 1-8, 2017.

[31] J. Restrepo-Osorio, D. P. Nobile-Correa, O. Zuñiga, and R. A. Sánchez-Andica, "Determination of nutritional value of turmeric flour and the antioxidant activity of Curcuma longa rhizome extracts from agroecological and conventional crops of Valle del Cauca-Colombia," Rev. Colomb. Quim., vol. 49, no. 1, pp. 26-32, 2020.
[32] S. C. Gupta, S. Patchva, W. Koh, and B. B. Aggarwal, "Discovery of Curcumin, a Component of the Golden Spice, and Its Miraculous Biological Activities," Clin Exp Pharmacol Physiol, vol. 39, no. 3, pp. 283-299, 2012.

[33] R. Suvarna, S. S. Bhat, and K. S. Hegde, "Antibacterial Activity of Turmeric against Enterococcus faecalis An In vitro Study," Int. J. Curr. Microbiol. Applide Sci., vol. 3, no. 2, pp. 498-504, 2014.

[34] N. Singh, S. Gupta, and V. Rathore, "Comparative antimicrobial study of ethanolic extract of leaf and rhizome of curcuma longa linn," Pharmacogn. J., vol. 9, no. 2, pp. 208212, 2017.

[35] S. Mishra and K. Palanivelu, "The effect of curcumin (turmeric) on Alzheimer's disease: An overview," Ann. Indian Acad. Neurol., vol. 11, no. 1, pp. 13-19, 2008.

[36] N. G. Vallianou, A. Evangelopoulos, N. Schizas, and C. Kazazis, "Potential Anticancer Properties and Mechanisms of Action of Curcumin," Anticancer Res., vol. 652, no. 35, pp. 645-651, 2015.

[37] M. Bomma, F. Okafor, S. R. Mentreddy, L. Nyochembeng, W. Setzer, and B. Vogler, "Comparison of Methods of Extraction and Antimicrobial Activity of Six Ocimum Species against Human Pathogens," J. Agric. Life Sci., vol. 5, no. 2, pp. 61-70, 2018.

[38] G. K. Naidu, C. S. K. Naidu, and B. Sujatha, "In Vitro Antibacterial Activity and Phytochemical Analysis of Leaves of Gymnema sylvestre," Int. J. PharmTech Res., vol. 5, no. 3, pp. 1315-1320, 2013.

[39] E. M. Tanvir et al., "Antioxidant properties of popular turmeric (Curcuma longa) varieties from Bangladesh," $J$. Food Qual., vol. 2017, 2017.

[40] A. Molan, A. Faraj, and A. Mahdy, "Antioxidant activity and phenolic content of some medicinal plants traditionally used in Northern Iraq," Phytopharmacology, vol. 2, no. 2, pp. 224 233, 2012.

[41] S. Chandra et al., "Assessment of total phenolic and flavonoid content, antioxidant properties, and yield of aeroponically and conventionally grown leafy vegetables and fruit crops: A comparative study," Evidence-based Complement. Altern. Med., vol. 2014, 2014.

[42] V. D. Tambe and R. S. Bhambar, "Estimation of Total Phenol, Tannin, Alkaloid and Flavonoid in Hibiscus Tiliaceus Linn. Wood Extracts," Res. Rev. J. Pharmacogn. Phytochem., vol. 2, no. 4, pp. 41-47, 2014.

[43] L. L. Mensor et al., "Screening of Brazilian plant extracts for antioxidant activity by the use of DPPH free radical method," Phyther. Res., vol. 15, no. 2, pp. 127-130, 2001.

[44] CLSI, Methods for Dilution Antimicrobial Susceptibility Tests for Bacteria That Grow Aerobically; Approved StandardNinth Edition. CLSI document M07-A9., vol. 32, no. 2. Wayne, PA: Clinical and Laboratory Standards Institute, 2012.

[45] CLSI, Performance Standards for Antimicrobial Susceptibility Testing. 27th ed. CLSI supplement M100. 2017.

[46] V. Katalinic, M. Milos, T. Kulisic, and M. Jukic, "Screening of 70 medicinal plant extracts for antioxidant capacity and total phenols," Food Chem., vol. 94, no. 4, pp. 550-557, 2006. 
[47] C. Y. Hsu, Y. P. Chan, and J. Chang, "Antioxidant activity of extract from Polygonum cuspidatum," Biol. Res., vol. 40, no. 1, pp. 13-21, 2007.

[48] D. Chohra, L. Ferchichi, Y. S. Cakmak, G. Zengin, and S. M Alsheikh, "Phenolic profiles, antioxidant activities and enzyme inhibitory effects of an Algerian medicinal plant (Clematis cirrhosa L.)," South African J. Bot., vol. 132, pp. 164-170, 2020.

[49] I. Ahmad and A. Z. Beg, "Antimicrobial and phytochemical studies on 45 Indian medicinal plants against multi-drug resistant human pathogens.," J. Ethnopharmacol., vol. 74, no. 2, pp. 113-123, 2001.

[50] S. Ramli, S. Radu, K. Shaari, and Y. Rukayadi, "Antibacterial activity of ethanolic extract of syzygium polyanthum L. (Salam) leaves against foodborne pathogens and application as food sanitizer," Biomed Res. Int., vol. 2017, 2017.

[51] H. Chandarana, S. Baluja, and S. V. Chanda, "Comparison of
Antibacterial Activities of Selected Species of Zingiberaceae Family and Some Synthetic Compounds," Turkish J. Biol., vol. 29 , no. 2, pp. 83-97, 2005.

[52] C. Thongson, P. M. Davidson, W. Mahakarnchanakul, and P. Vibulsresth, "Antimicrobial effect of thai spices against Listeria monocytogenes and Salmonella Typhimurium DT104," J. Food Prot., vol. 68, no. 10, pp. 2054-2058, 2005.

[53] H. Ramadan et al., "Antibacterial activity of Pomegranate, Orange and Lemon peel extracts against foodborne pathogens and spoilage bacteria In vitro and on poultry skin," Int. $J$. Poult. Sci., vol. 14, no. 4, pp. 229-239, 2015.

[54] M. M. Cowan, "Plant products as antimicrobial agents.," Clin. Microbiol. Rev., vol. 12, no. 4, pp. 564-82, 1999.

[55] M. Miklasińska-Majdanik, M. Kępa, R. D. Wojtyczka, D. Idzik, and T. J. Wąsik, "Phenolic compounds diminish antibiotic resistance of staphylococcus aureus clinical strains," Int. J. Environ. Res. Public Health, vol. 15, no. 10, 2018. 